\title{
After Boyology, Or, Whence and Whither Boyhood Studies?
}

\author{
Diederik F. Janssen
}

$\infty \infty$

\begin{abstract}
If I were writing a treatise on natural history, and wanted to define the animal 'boy,' I should be greatly puzzled. That is, I should be greatly puzzled if I relied upon 'authorities;' for they do not differ more respecting the chronology of Manetho or the object of the Great Pyramid than they do in reference to the characteristics and qualifications of the said animal. (Anon. 1880: 1-2)

Truly boyhood is a study, but it is one of those studies not yet reduced to a science. In short, it is doubtful whether we can ever reduce the study of boys to a science. If we could, it would be called 'Boyology', but we can not secure even a general classification of facts concerning him.” (McAlpine 1887: 96)
\end{abstract}

I am most excited to be announcing the first issue of Boyhood Studies: An Interdisciplinary Journal. The journal continues Thymos: Journal of Boyhood Studies, seven volumes of which were published between 2007 and 2013 by The Men's Studies Press. Boyhood Studies will complement Berghahn's prize-winning title Girlhood Studies: An Interdisciplinary Journal, published as of 2008.

Having co-nurtured Thymos, initially with Miles Groth of Wagner College, on the basis of two exploratory bibliographies on boyhood and girlhood studies (unofficially web-published first in June 2005), I feel thrilled about the vitality and now co-residence of both journals ten years onward. Over the years, both journals have featured a wide range of scholarship, and have been helpful in imagining what, thereby, became eponymous fields of scholarship. I am most privileged to be able to thank both Dr. James Doyle of The Men's Studies Press for his unrelenting dedication, his energy, and continued intellectual companionship, and Vivian Berghahn and the Berghahn production team, for their vision, support, and hard work in making this re-launch a possibility. 


\section{Boyhood Studies: Whence and Whither}

Whence the will to understand boys? What goes into @BoyhoodStudies or \#BoyhoodStudies? Since it is not immediately obvious where boyhood studies has been and where it is heading, I will take a few paragraphs to consider both questions, without intending to resolve them. Apart from the spring 2007 editorial introduction and a fall 2009 roundtable in Thymos, boyhood studies has received neither the lively territorial negotiations, nor the community formation witnessed around girlhood studies. Most of today's rare scholarly platforms dedicated to the study of the young male restrict themselves to the (laudable) scope of education, an example being the online Journal of African American Males in Education published as of 2010. To my knowledge there are as yet no boy pendants of the International Girls Studies Association (founded in 2011), of Tyttötutkimusverkosto, The Finnish Network for Girls' Studies (founded in 2006) and FlickForsk! Nordic Network for Girlhood Studies (founded in 2008), of various Girls' Studies Minor programs and Girls' Studies courses, occasional journal sections on girlhood studies such as the one in Feminist Media Studies (Mendes et al. 2009), recent girls' studies conferences, nor of edited books and monographs dedicated to the imagining of girls' studies.

The question of how to factor in boys across global feminisms and gender mainstreaming projects worldwide, which may be key to the intellectual marketability of the research fields under discussion, perhaps echoes the still somewhat stalemated men-in-feminism debates of the latter half of the 1980s. Even today, the question of what to do with or what to make of literature published under the imprimatur of men's studies seems burdened with a range of not always clear academic sensibilities. That masculinity studies aligns with feminist theory is clear but there are many possible directions of such an alignment (Gardiner 2002). Inevitably, then, how boyhood studies was going to be received, even within men's studies, was a bit of a gamble. Possibly illustrative of enduring modes of division and oversight in today's gender studies ecosystem, Sharon Lamb's contribution to the already mentioned 2009 special section in Feminist Media Studies was in fact a (doubting and lukewarm) call for a Boyhood Studies journal—which she, and her commissioning editors, overlooked had been in existence for two years. (Of note, Lamb would release a co-authored book that same year on how boyhood was being "packaged" in the media: Lamb, Brown and Tappan 2009.)

Unsurprising given the late mainstreaming of men and masculinities both within and alongside the scene of women's studies, in any case, the 
contours of a post-second-wave-feminist girlhood studies do seem to have antedated those of boyhood studies. An early Anglophone volume was edited by Dutch researchers Marion de Ras and Mieke Lunenberg in 1993. The Dutch term meisjesstudies (girls' studies), was introduced in a 1991 volume (edited by Ineke van der Zande) meant as an introduction to the field. The equivalent German term Mädchenforschung and the recognition of its timeliness, incidentally, are attested to at least as far back as a short paper by Hannelore Faulstich-Wieland published in 1985. Linda Duits and Liesbet van Zoonen date back a girl focus in youth studies to work published in the mid-1970s (2009).

Since their intellectual demarcation during the early 1980s and move into scholarly focus and periodicals in the early 1990s (see Doyle and Femiano 1999), within American men's studies and men-against-sexism contexts, boys have for a long time enjoyed only an arguable and implicit centrality. Among the finest of historical and anthropological studies of masculinity in the early 1980s, however, many dealt with male initiation and socialization. Formal recognition of the puzzle and plight of boys had been there although such recognition was mostly West-European (and regional at that) and mostly applied either to boys in education or more broadly to youth work with boys. Illustrative and noteworthy is the German-language magazine Switchboard: Zeitschrift für Männer und Jungenarbeit, published since 1989, that focuses partly on youth work with boys. (It is to be renamed Heartbeat as of 2015). Allusions to a more encompassing Jungenforschung (boys studies), within the concentric German purviews of Geschlechterforschung (gender studies) and Männerforschung or Männerstudien (men's studies), have long remained peripheral to Anglophone gender studies. They go back, incidentally, to a 1993 article by TU Dortmund University women's studies pioneer Sigrid Metz-Göckel, published in Zeitschrift für Frauenforschung (the German Journal of Women's Studies).

In the Anglophone literature, contemporary research on boys and gender has accreted mostly around the vistas of Education and Masculinities, the title of a recent book by Haywood and Mac an Ghaill (2013), substantially outlined already in Mac an Ghaill (1994), and, more inclusive, Young Masculinities (the title of a 2001 book by Frosh, Phoenix, and Pattman). "Young masculinities" certainly resonated with what we had in mind in imagining boyhood studies in the mid-2000s. Yet masculinities, with heavily implied theoretical vantage points (especially the conceptual move by R.W. Connell c.s. from earlier notions of "male hegemony" to "hegemonic masculinity", a move notably applied to gender configurations in schools already in its 
earliest discussions: Kessler, Ashenden, Connell and Dowsett 1985), while of obvious interest, appeared to us too meager, etic, what we might call genderist, and intellectually unresponsive to allow an inclusive and free-ranging inquiry into boys', or men's, lives. These lives could not, even where suffused by its stipulations, be reduced to an economics of intra- and intersexual rivalry, we thought. If notions of rivalry and of fitness, and metaphors such as patriarchal dividend duly identify the key economic and evolutionary bass lines in the imaginaire of society, the question remained, for us, how boys and the men they (except one!) grow up to be should be attuned to the historical materialist drone sustained across milestone publications of the masculinities studies movement. Theory risked, indeed forever risks, getting in the way of understanding what might be there for the theorizing. To us, the masculinities literature generated more questions than it did answers, yet fewer questions than were welcome.

Observing Connell's historical centrality to the establishment of masculinity as a transdisciplinary research focus in the mid-1980s, we acknowledge the fact that already in the early 1980s Connell published widely on gender and class in education and families, and today continues to focus on education. With boyhood studies we had in mind, rather, the open-ended, wide-angled inquiry into the idea, trope, lore, and imago of the boy precisely as it was hotly contested across the centuries and sciences, at times celebrated and aestheticized, at others submitted into an accountancy of cultural capital and representational fairness, ultimately precariously lived across cultures. Somewhat coextensive with our scope was the interdisciplinary focus of childhood and youth studies (compare Janssen 2012), in any case not a definitive settling on this or that gender critical angle, or typological grid, or camp. At this point I believe we have largely remained in agreement with our sister field of girlhood studies.

Any intellectual nonpartisanism risks being taken as expressing naivety, disengagement or even disingenuousness from an activist perspective. Anyway, a viewpoint-inclusive and controversy-friendly scope has been, and in my view remains, worth the risks, and arguably marks the most convincing of feminist works as well. As for Thymos, such a scope has never precluded discussions centered on gender critique or reform. Ideas and sentiments concerning what to do with or about gender will differ and differ strongly, as they have for decades within and increasingly far beyond Anglo-European gender studies. Gender justice is a wandering target, and its interest lies importantly in the circumstance that it is only one of many targets moving about_-points incessantly and duly made by most feminists for decades. 
Long before the consolidation of masculinity studies historians and anthropologists have observed that notions of boyhood have plugged deeply into visions of empire, nationhood, sexual hygiene, class, and race (compare Alexander and Collins, this issue). Regardless, what the most urgent questions about gender/genders should be may impress somewhat differently every day_-something well-pondered for decades as well, whether with or without recourse to notions such as postfeminism.

Some have lamented that boyhood studies and girlhood studies have proven separate playgrounds given their arguably distinct scholarly heritage and consequently divergent relation to feminist theory (Coulter 2012). Others have duly questioned the implied territoriality of both by looking at the historically recent gender mobility of grrrls and bois along with "phallic girls" (Renold and Ringrose 2012: 48), and "alpha girls" (Kindlon 2006: 6). Accordingly, girlhood is importantly how it might want to come across: "neither an age nor a stage, but ... an ironic and iconic performance infused with youthful energy, style, fun, and capriciousness" (Pomerantz 2009: 154). Thus advanced beyond their respective $O E D$ definitions, such a generative conception of girlhood could easily be wrapped around boyhood-but perhaps not without summoning all the other unstable and ironic coordinates of identification and disidentification that animate and police contemporary boyhoods. Anglophone and netizen boys move about in a soundscape of dudes, guys, kidz, kiddos, bruhs, dawgs, brothas, homeys, cuz's, Gs, ésos, vatos, mates, blokes, lads, chavs, and a range of other more or less glocal honorary vocatives, quasi-epithets, and cyber-colloquialisms. If it is pure nostalgia, or simply empirically wrong, to still consider men or boys the keywords of this often tendentious but in principle boundless lexical play, one might still want to see precisely into what (gender) trouble, at the present historical juncture or at others, this assumption gets the researcher.

Semantically, boyhood asserts analytic distance and hindsight. It has an anachronistic ring to it that its nouveau pluralization (Corbett 2009) has a hard time undoing. The word is rare before the late eighteenth century, according to the OED. Unlike childhood, both girlhood and boyhood's British and American English ngrams show a slow rise from 1800 to a peak around 1900 and a steady decline soon after. Twentieth century youth vocabularies have never needed the term. Like the itinerary called coming of age, there is something compelling, cinematic, and humanizing in recounting boyhood when one cannot lay claim to it any longer-but to make a lot of it would also have to make it something regressive and sentimental, even something outmoded if not imminently unsavory, whether 
something suspiciously recuperative or something unmanly, queer. Notwithstanding, boyhood is as timely as being the title and topic of 2014's winner of the Golden Globe Award for Best Motion Picture-Drama and of the BAFTA Award for Best Film, and a six-fold Oscar nominee including one for Best Motion Picture of the Year. Written and directed by Richard Linklater, Boyhood was shot intermittently over the course of a twelve-year period, following a Texan boy from age six to eighteen. How the apparent appeal of such a prospective and visual study of one boy's life speaks to the standing of social scientific approaches to boyhood is open for speculation (which is hereby invited).

There is something in the singular boyhood, perhaps, that resists being put into words (such that the moving picture becomes all the more compelling), or rather, something that would chime poorly with today's guarded poetics of gender critique (such that yesterday's keywords become shy and make way for analytic paraphrases such as young masculinities). Bibliographers know the word has more often than not announced autobiography, edifying biographies of Extraordinary Men and other Men of Note, bittersweet poetry, and-if science-history, psychoanalysis, occasionally ethnography. Most of these genres have felt the violence of Time. In their arguable aftermaths, one is tempted to read the variegated turns and returns in Western literature and academe to male pasts and to less-than-advanced male cultures as illuminating men's privileged and increasingly their problematized positioning within history. They seem expressions of the correspondingly shifting intrigue of men's becoming. Revisiting and returning have more than once been characterized as the central reflex and fate of many modern men's lives (for observations on the male autobiographical impulse in the nineteenth century see Jacobson 1994). There is no shortage today of nostalgic, mythopoetic, neo-ritualist, and orthodoxy-reinstating tendencies in contemporary male cultures.

How divergently men look back on and make sense of what happened can perhaps be inferred from the degree to which there has been a scattering of men's studies, masculinity studies, profeminism, new male studies, men's rights, male psychology, and mythopoetic men's movements over the past decades. Unavoidably, boyhood studies will find itself centrally implicated in their confrontations and controversies - most of them ongoing and unresolved - as they negotiate the legacies and standing of men and the masculine across today's changing social landscapes.

Such an inevitable localization of the field - amidst all manner of masculinist and feminist controversy_allows a reposing of the historical ques- 
tion, and allows a reconsidering of the questionability, of understanding boys. Naturally, boyhood studies becomes an explicit agenda only in the historical moment it has stopped being obvious what to think of boys. Although I will not attempt it here, it would be interesting to look at boyhood studies reflexively as an historical phenomenon, as the embattlement of general perspectives and theses on the natures and cultures of masculine development, an accompaniment to the rapid changes in the law and lore informing male initiations, apprenticeships, and, ultimately, debts to society.

The historical work on American boyology—by David Macleod (1982), Kenneth Kidd (2004), Ken Parille (2009), Nancy Lesko (2012) and, most recently, Julia Grant (2014) — has amply illustrated how male passions, anxieties, and visions concerning what was happening, or was to happen, to the social and domestic order in the nineteenth century and beyond have strongly colored the ways in which expertise, initially mostly men's, over boys as boys came to be cultivated. Mentioned references are part of what might be called a post-boyological literature that sets out to historicize, unpack, and contexualize how, and at the occasion of which social changes, boys became knowable as boys, and boyhood became problematized as such. The authors of the four most recent books cited also stress that boyologists' classic concerns, claims, and conjectures have had plenty of contemporary reappearances. With post-boyology, then, one may tentatively distinguish not so much a temporally distinct as a gradual analytic shift in representations of boys, from the evangelical and ecumenical to the deconstructive and anti-normative. It implies a shift in appraising representations of boys' nature, a new reading for their circumstances and beneficiaries, their sponsorships, tacit assumptions, silent complicities, poetic conventions, intertextuality, regulatory implications, exclusions, and erasures. While such a reading has been advanced already in the discussions of boy books in 1930s literary criticism (see, for example, Roller 1931) if not earlier, the historians cited above for the first time focused comprehensively on the intellectual basis of what social historian E. Anthony Rotundo called nineteenth century's "boy culture" (1990: 15).

If this occasion of periodization permits me a minor lapse into trivia, Kidd takes the cheeky word boyology from YMCA leader Henry William Gibson's 1916 tract Boyology, or Boy Analysis and a 1914 lecture series by E.P. Conlon. It had been in somewhat more extensive use, however, both positively, as the title of a boys' work conference held in Texas (Jameson 1908: 34), and derogatorily, naming a project engaged in "by men and women with large intellects and spectacles" who will "study [the boy] and 
classify his traits and characteristics" but ultimately not help him (Hungerford 1903: 42). In line with established periodizations of boyology, the term in fact occurs first across the pond and decades before the floruit of $\mathrm{G}$. Stanley Hall, known as the father of the child study movement, indeed as early as an 1868 review of Stories of School Life by Ascott R. Hope (1868) that appeared in the Edinburgh Courant. Young dominie (schoolmaster) and Scotchman Hope's books were filled with reminiscences and sympathetic character sketches of the schoolmasters and schoolboys who inhabited his own schooldays and had surrounded him ever since in his profession. In $A$ Book about Boys (1868) he set out to provide what he thought could well be the first monographic account of the nature and ways of boys. Drawing from the British and French school experience, he focused on favored types of boys and not others, but would eventually follow up with accounts of the world's variety of boyhoods in his $1882 \mathrm{~A}$ Book of Boyhoods.

If Hope was the first nominated boyologist writing in the English language, he was never without competition: "I believe that on no subject has more nonsense been talked during the last few years than about boys" (1867: 31). In Hope's days, "the acquaintancy of Mrs. Grundy" and "Social Science," in any case the "foolish cry of fond mammas and foolish philanthropists" (1868: 51), were to be skeptically scrutinized for their correspondence with boys' nature. Our times predispose us to look back critically on this early scramble for expertise, the anecdotal, biographic, and parochial bent of which was eventually to be superseded by the increasingly more dispassionate genetic psychology, paidology (Chrisman 1894), or child-study, of the early 1890s. But it has been observed more than once that G. Stanley Hall's concept of adolescence was in fact largely that of a boy's adolescence (I won't mention Freud), and that Hall can securely be called the most important boyologist of his age.

In fact, it might pay to risk the conjecture that boyology was father to childhood studies. Conferences and meetings of the standing committees on Boys' Work in the Young Men's Christian Associations (YMCAs), instituted from the early 1880 s onward, already provided regular occasions to explore the managerial, vocational, and pedagogical challenges of working specifically with the (Christian) boy demographic. A rich academic portfolio of boy study issues was covered at the 1899 annual International Conference of YMCA Physical Directors, for instance, with topics ranging from the question of "How to Secure and Maintain Permanent Interest of Boys in Physical Training" to the "Pedagogical Aspect of the "Gang Instinct" (Anon. 1899: 92-93). And with adolescent psychology well under way, sci- 
ence rarely stopped being gendered at its core. The author of a 1915 book review spelled out the stakes. "We want more teachers who have had courses in boyology and girlistics, who have perfected themselves in the knowledge of what qualities of superb manhood and womanhood are, and by what exercises those qualities are encouraged toward perfection" (McAndrew 1915: 498).

While some of the "troubles of boys" signaled out by Hope (1868: 3572) have ceased to exist, at times pace Hope (he would not spare the tawse [an implement of corporal punishment], for instance), many dimensions of boyhood centralized by Hope, including boys' scholastic aptitude, their friendships, and their relation to schoolmasters and (avant la lettre) role models, are still found to be central to the way boys demand to be understood. Strictly speaking, if boyology entailed a renegotiation of boys' nature in the shifting light of social conditions, most of today's developmental, men's and even feminist psychology continues its project explicitly or implicitly. Denials of naturalness can rarely avoid making an empirical claim. And if boyologists often seemed not to clarify the social predicament of boys but rather deployed "the boy" (Parille 2009: xv) as a vehicle for social commentary and engineering, one question seems to be an enduring one: how to read their poetics of naturalness. Stripping away all the layers of politics and interest, as one is accustomed to doing today, should one not admit that one may well want to end up with what is precisely natural to the boy?

Boy-expertise has long fanned out from its germinative contexts of empire building, religious conversion, world and gender wars, racial clashes, and class struggles. Some of these frames have been painted over many times but are still there. New frames have been closing in on the boy, too. Some discussions about boyhood have been recast in neurodevelopmental and evolutionary terms. Some have been encrypted in medical and psychiatric terms (especially along the so-called conduct, attention, social, and sexual dimensions of development), inviting a researcher's, and a culture's, courage to decrypt.

In Anglophone writings there has always remained a classic boyological penchant to build nations along with boys' character, to fight wars, to solve crises, and to diagnose performance lags — in ways that would, finally, compliment boys' true nature and potential. The trope of boys' nature, in short, remains very much tied up with how the just and good life is envisionedand offered up as an article of insight and as a token of pedagogical goodwill. If boyhood calls forth nineteenth century excesses at this point, the figure of the boy is still very much upon us, both as a social scientific shorthand and a metonym of cultural direction. It demands continued hindsight. 
Indeed, the boy is rarely not in crisis. A special section on the arguability of today's boy crisis theme can be found in this inaugural issue of Boyhood Studies, as introduced by its guest co-editors Máirtín Mac an Ghaill, Chris Haywood, and Jonathan Allan. Contributions to this section are timely since recent research does not straightforwardly underwrite the tried tropology of war, crisis, and lagging-behind, nor does it definitively solve the major questions it has animated. Female advantage in Western school marks seems to have remained stable across a century of measurement, contradicting claims of any particularly recent boy crisis in school achievement (D. Voyer and S. Voyer 2014). This does not yet tackle the problem of explaining disparities between sex gaps in achievement tests, in actual school performance, and in employment, leadership, and salary outcomes. Stoet and Geary (2015) reported that with the exception of high achievers, 15-year-old boys show poorer educational outcomes than 15-year-old girls pretty much around the world. The study notably reported no systematic, causal relation between educational outcome and social equality indicators (see also Reichert, this issue). Of further note, the countries where most of the boy crisis discourse was first and still loudest (the US and England) were among the very few (4 percent) where this overall sex gap tended to a (barely significant) reversal.

Boyhood studies may offer a stage for the work only hinted at here: the interpretation and unpacking of gender data-indeed of gender offered up as a demographic given. Most of the young masculinities focus of the past decades has set out to illuminate how gender is suffered, celebrated, conferred, and traded by and around boys, and how these operations relate to past and present theories about what was consecutively called psychosexual development, sex role development or gender identity development, and to gender justice. As said, one is dealing with moveable targets here. With the ubiquity of gender identity as a once clinical, then Western social scientific, finally global-cultural trope comes new varieties of living and understanding gender - and with lively variety, new biotopes of meaningfulness.

It is here that boyhood studies has a role to play in the wider historical project of gender studies and in the imagining of boys' lives. Elements of performance, irony, and parody have long been thematized in gender studies and childhood studies alike, and they may be central to appraisals of young masculinities. They are taken to articulate maturity (as intelligent interventions into, or informed distance to, the violence of the Serious and Established) but also immaturity (as symptoms of decompensation and disengagement). They speak directly to the perennial allegation of perpetual adolescence in men, and are consequently critical in a cultural localization 
of any boyhood studies. What makes gender serious, or mature? Who (still) takes gender seriously, and who too seriously? How adult-minded must its studies and theories be? I mean this: if one insists anywhere where the boys are on finding reigning or barely survived hegemons, how can one make sure this way of typologizing power has not become a way of holding onto, indeed an unending projection of, the same Angstbild? In programmatically taking apart (boyish) genders, how can we make sure we are not in fact insisting on their original solidity? Comparable quandaries have been gnawed at within the queer theoretical tradition for a quarter of a century, and many seem critical to mapping twenty-first century boyhoods (see Mac an Ghaill and Haywood 2012).

If boyhood's sense of datedness is taken to refer to its poetics and aesthetics of essence (its nostalgic essentialism, especially), its eponymous studies will require an engagement with these quandaries. One gets the idea when briefly observing the largely North-American, importantly YouTubesponsored, culture of backyard wrestling. Backyard wrestlers re-enact the pro wrestling scene, which theatricalizes nineteenth-century catch wrestling, which, like boxing, stylized otherwise brutal fights into civil duels and civilizing sports. It makes for a silly archive, to speak with Judith Halberstam (via Lauren Berlant: Halberstam 2011: 20), of male burlesque: heels vs faces, payoffs, run-ins, cheap heats. Epic battles are staged on a makeshift wrestling ground, trampoline for canvas, ropes from which to bounce or jump off of or slam into, with the fair fight forever fading into the unruly and untoward. It has all the athlete, nemesis, team, manager, announcer, referee, commentator, interviewer and spectator folklore you come to love or love to hate. Risking pain and spinal injury, some of the boys - or their garden-variety gimmicks? - envision a career, their exploits edited and uploaded, their world tour already started. Some are five years old, some are twenty-five. Some are proudly so-called white trash, others are too young to appreciate the compliment. Some score millions of views and thousands of comments. Apropos: how to view and comment? This junior wrestlemania may have larger stories - existential, dramatic, tragi-comic — to tell than strictly those of male development, hegemonic masculinity, or the neurobiology of rough-and-tumble play. Its mode of maxed-up maleness makes for a monument to the many layers in suffering the battle of being. If there is a boyish nature expressed in this American form of Geertzian "deep play" (via Jeremy Bentham: Geertz 1973: 432), it will require a patient anthropologist's eye.

As originally envisioned in Thymos, we hope that Boyhood Studies: An Interdisciplinary Journal will be of help in making sense of all the awards, 
nominations, views, comments, and criticism that boy culture is, apparently, able to elicit. What (analytic) gaze do boys, young and older, deserve? What spectacle do they present to the observing eye, beyond that of the remnants or ruins of patriarchy? What do boys need from teachers, parents, friends, and loved ones? What are the latter asking of the boy? Historical, anthropological, and practice-based contributions are all welcomed-they are all needed-to answer these global questions.

DIEDERIK F. JANSSEN is an independent researcher residing in Nijmegen, The Netherlands. A co-founder and later editor of Thymos: Journal of Boyhood Studies (The Men's Studies Press 2007-2013), he is editor of Boyhood Studies: An Interdisciplinary Journal (Berghahn Journals), founding and current editor of Culture, Society \& Masculinities (The Men's Studies Press), and managing editor of The Journal of Men's Studies (Sage). Email: diederikjanssen@gmail.com

\section{References}

Anon. 1880. Boys and Their Ways. A Book for and about Boys, by One Who Knows Them. London: John Hogg.

Anon. 1899. "International Conference of Y.M.C.A. Physical Directors." Mind and Body 6, no. 64: 92-93.

Chrisman, Oscar. "Child-Study: A New Department of Education." Forum 16: 728-738.

Corbett, Ken. 2009. Boyhoods: Rethinking Masculinities. New Haven, CT: Yale University Press.

Coulter, Natalie. 2012. "Separate Playgrounds: Surveying the Fields of Girls' Media Studies and Boyhood Studies." Canadian Journal of Communication 37: 353-362.

de Ras, Marion, and Mieke Lunenberg, eds. 1993. Girls, Girlhood and Girls' Studies in Transition. Amsterdam: Het Spinhuis.

Doyle, James, and Sam Femiano. 1999. "The Early History of the American Men's Studies Association and the Evolution of Men's Studies." http:// mensstudies.org (accessed May 1, 2010)

Duits, Linda, and Liesbet van Zoonen. 2009. "Against Amnesia: 30+ Years of Girls' Studies." Feminist Media Studies 9, no. 1: 111-115.

Faulstich-Wieland, Hannelore. 1985. "Mädchen—Die vergessenen Hälfte der Jugend? Zum Stand der Mädchenforschung." Zeitschrift für Sozialisationsforschung und Erziehungssoziologie 5, no. 1: 145-150. 
Frosh, Stephen, Ann Phoenix, and Rob Pattman. 2001. Young Masculinities: Understanding Boys in Contemporary Society. Houndsville, UK: Palgrave Macmillan.

Gardiner, Judith Kegan, ed. 2002. Masculinity Studies and Feminist Theory: New Directions. New York: Columbia University Press.

Geertz, Clifford. 1973. The Interpretation of Cultures. New York: Basic Books. Gibson, Henry William. 1916. Boyology, or Boy Analysis. New York: Association Press.

Grant, Julia. 2014. The Boy Problem: Educating Boys in Urban America, 18701970. Baltimore: Johns Hopkins University Press.

Halberstam, Judith. 2011. The Queer Art of Failure. Durham: Duke University Press.

Haywood, Chris, and Máirtín Mac an Ghaill. 2013. Education and Masculinities:

Social, Cultural and Global Transformations. New York: Routledge.

Hope, A.R. 1867. A Book about Dominies. Edinburgh: William P. Nimmo.

Hope, A.R. 1868. A Book about Boys. Edinburgh: William P. Nimmo.

Hope, A.R. 1882. A Book of Boyhoods. London: John Hogg.

Hungerford, Herbert. 1903. "How to Form a Boys' Club." Success 6 (January):

42.

Jacobson, Marcia. 1994. Being a Boy Again: Autobiography and the American Boy Book. Tuscaloosa: University of Alabama Press.

Jameson, A.A. 1908. "The Boys." Association Men 34, October: 34.

Janssen, Diederik F. 2012. "Masculinities/Boyhood." In Oxford Bibliographies in Childhood Studies, ed. Heather Montgomery. New York: Oxford University Press.

Kessler, S., D.J. Ashenden, R.W. Connell and G.W. Dowsett. 1985. "Gender

Relations in Secondary Schooling." Sociology of Education 58, No. 1: 34-48.

Kidd, Kenneth B. 2004. Making American Boys: Boyology and the Feral Tale.

Minneapolis: University of Minnesota Press.

Kindlon, Dan. 2006. Alpha Girls: Understanding the New American Girl and How She is Changing the World. New York: Rodale.

Lamb, Sharon, Mikel Brown, and Mark Tappan. 2009. Packaging Boyhood:

Saving Our Sons from Superheroes, Slackers, and Other Media Stereotypes. New York: St. Martin's Press.

Lesko, Nancy. 2012. Act Your Age!: A Cultural Construction of Adolescence (2nd ed.). New York: Routledge.

Mac an Ghaill, Máirtín, and Chris Haywood. 2012. "The Queer in Masculinity: Schooling, Boys, and Identity Formation.” Pp. 69-84, in Queer Masculinities: A Critical Reader in Education, ed. J.C. Landreau and N. Rodriguez. New York: New York University Press.

Mac an Ghaill, Máirtín. 1994. The Making of Men: Masculinities, Sexualities and Schooling. Buckingham: Open University Press. 
Macleod, David. 1983. Building Character in the American Boy: The Boy Scouts, YMCA, and Their Forerunners, 1870-1920. Madison: University of Wisconsin Press.

McAlpine, Frank. 1887. Mile-Stones of History, Literature, Travel, Mythology, Sculpture, and Art. Chicago and Philadelphia: Elliott \& Beezley.

McAndrew, William. 1915. "Psychology of High School Subjects. By Charles Hubbard Judd” [Book review]. The School Review [University of Chicago] 23: 497-500.

Mendes, Kaitlynn, Kumarini Silva, Linda Duits, Liesbet van Zoonen, Sharon Lamb, Shakuntala Banaji and Natalie Edwards. 2009. "Commentary and Criticism: Girls, Boys, and 'Girlhood' Studies." Feminist Media Studies 9, no. 1: 109-125.

Metz-Göckel, Sigrid. 1993. "Jungensozialisation, oder: Zur Geschlechterdifferenz aus der Perspektive einer Jungenforschung." Zeitschrift für Frauenforschung 11, nos. 1-2: 90-110.

Parille, Ken. 2009. Boys at Home: Discipline, Masculinity, and "The Boy-Problem" in Nineteenth-Century American Literature. Knoxville: University of Tennessee Press.

Pomerantz, Shauna. 2009. "Between a Rock and a Hard Place: Un/Defining the 'Girl.'” Jeunesse: Young People, Texts, Cultures 1, no. 2: 147-158.

Renold, Emma, and Jessica Ringrose. 2012. "Phallic Girls? Girls' Negotiation of Phallogocentric Power." Pp. 47-67 in Queer Masculinities, ed. John C. Landreau and Nelson M. Rodriguez. Dordrecht, Netherlands: Springer.

Roller, Bert. 1931. "The 'Bad Boy' in American Literature." Peabody Journal of Education 8, no. 5: 291-296.

Rotundo, E. Anthony. 1990. "Boy Culture: Middle-Class Boyhood in Nineteenth Century America.” Pp. 15-36 in Meanings for Manhood: Constructions of Masculinity in Victorian America, ed. M.C. Carnes and C. Griffen. Chicago: University of Chicago Press.

Stoet, Gijsbert, and David C. Geary. 2015. "Sex Differences in Academic Achievement Are Not Related to Political, Economic, or Social Equality." Intelligence 48: 137-151.

Van der Zande, Ineke, ed. 1991. Het is Meisjes Menens. Inleiding Meisjesstudies. Amersfoort: Acco.

Voyer, Daniel, and Susan D. Voyer. 2014. "Gender Differences in Scholastic Achievement: A Meta-Analysis.” Psychological Bulletin 140, No. 4: 11741204. 